\title{
Nutritional evaluation of babassu endocarp meal type II with different inclusions in sheep diets ${ }^{1}$
}

\section{Avaliação nutricional de dietas para ovinos com diferentes níveis de inclusão de farinha do endocarpo tipo II do babaçu' ${ }^{1}$}

\author{
Hemilly Cristina Menezes Sá2*; Iran Borges ${ }^{3}$; Gilberto de Lima Macedo Junior ${ }^{4}$; \\ José Neuman Miranda Neivas; Tássia Ludmila Teles Martins²; \\ Joana Palhares Campolina²
}

\begin{abstract}
Industrialization of the Babassu coconut for edible oil production generates many co-products and has great potential to be used in ruminant nutrition. The aim of this study was to evaluate the effect of different inclusions of endocarp meal type II of Babassu coconut (BEMII) on intake and digestibility of sheep diets. Twenty non-castrated male sheep with an undefined breed were distributed in a completely randomized design with four treatments and five replications. The animals received an experimental diet with increasing inclusions of BEMII $(0.0 \%, 7.5 \%, 15.0 \%$, and $22.5 \%)$. Increasing additions of the coproduct negatively influenced dry matter intake $\left(\mathrm{g} / \mathrm{BW}\right.$ and $\left.\mathrm{g} / \mathrm{kg}^{0.75}\right)$. Crude protein intake (in grams) per day decreased linearly with the inclusion of BEMII, presenting a reduction of $49.35 \mathrm{~g} / \mathrm{d}$. The inclusion of $7.5 \%$ showed the best response for energy balance among all inclusions and presented the closest nitrogen balance value when compared to the control group; therefore, this inclusion percentage is the best for endocarp meal utilization.
\end{abstract}

Key words: Co-product, fiber, lambs, palmae

\section{Resumo}

A industrialização do babaçu para produção de óleo comestível gera muitos co-produtos com grande potencial para serem usados na nutrição de ruminantes. O objetivo deste estudo foi avaliar o efeito de diferentes inclusões da farinha do endocarpo tipo II do babaçu (FEBII) sobre o consumo e digestibilidade de dietas para ovinos. Vinte ovinos machos, sem raça definida, não castrados, foram distribuídos em um delineamento experimental inteiramente ao acaso com crescentes inclusões da FEBII $(0,0,7,5 \%$; $15,0 \% ; 22,5 \%)$. O consumo de matéria seca em função do peso vivo e do peso metabólico foram influenciados negativamente pelas inclusões crescentes do co-produto (g.Peso Vivo ${ }^{-1}$ e g.kg. $g^{0.75}$ ). O consumo de proteína bruta em g por dia respondeu de forma linear decrescente com a inclusão da FEBII apresentando redução de 49,35 g por dia em comparação a $0 \%$ de inclusão e $22,5 \%$. O teor de $7,5 \%$

1 Trabalho financiado com recursos do CNPq e SECT-TO. Trabalho pertencente à dissertação de mestrado da primeira autora.

2 Discentes de Doutorado em Nutrição Animal, Universidade Federal de Minas Gerais, UFMG, Escola de Veterinária, Dept ${ }^{\circ}$ de Zootecnia, Belo Horizonte, MG, Brasil. E-mail: hemilly.mg@hotmail.com; talutema@yahoo.com.br; joana.campolina@yahoo.com.br

${ }^{3}$ Prof., UFMG, Escola de Veterinária, Dept ${ }^{\circ}$ de Zootecnia, Belo Horizonte, MG, Brasil. Bolsistas de produtividade do CNPq. E-mail: iran@vet.ufmg.br

${ }^{4}$ Prof., Universidade Federal de Uberlândia, UFU, Faculdade de Medicina Veterinária e Zootecnia, Uberlândia, MG, Brasil. E-mail: gilbertomacedojr@gmail.com

5 Prof., Universidade Federal de Tocantins, UFT, Araguaina, TO, Brasil. Bolsistas de produtividade do CNPq. E-mail: araguaia2007@ gmail.com

* Author for correspondence 
foi o melhor entre as inclusões para o balanço energético e apresentou valor muito próximo no balanço nitrogenado em relação ao grupo controle, chamando atenção especial para esta inclusão, inserindo-a como o melhor ponto de utilização do subproduto.

Palavras-chave: Cordeiros, co-produto, fibra, palmae

\section{Introduction}

The Babassu palm tree is found more frequently in transition zones between the Amazon rain forest and semi-arid lands of the Brazilian Northeast. In Maranhão state, there are about 10 million ha of this tree. In the high-density area in Piauí state, there are more than $200 \mathrm{palms} / \mathrm{ha}$ (SOUZA et al., 2011). The physical composition of the Babassu (Orbignya sp.) is indicated by four usable parts: epicarp (11\%), mesocarp (23\%), endocarp (59\%), and almond (7\%) (SOLER et al., 2007). Industrialization of the Babassu coconut for edible oil production generates many co-products with great potential to be used in ruminant nutrition.

Current researches seek the chemical composition of Babassu co-products and their inclusion level recommendations, such as Babassu meal and cake (ABDALLA et al., 2008; SOUSA JUNIOR et al., 2007; XENOFONTE et al., 2008), as well as mesocarp meal type II and I (MIOTTO et al., 2012; SOUSA et al., 2014). However, to our knowledge, no research has provided inclusion level recommendations for ruminant diets with Babassu endocarp meal types II and I. The objective of this study was to evaluate the effects of Babassu endocarp meal type II (BEMII) at various inclusion levels to determine the intake and digestibility of diets for undefined lambs.

\section{Material and Methods}

The experiment was conducted in the sheep and goat farming sector of the School of Veterinary Medicine and Animal Science on Araguaína campus at the Federal University of Tocantins. Babassu endocarp meal type II (BEMII) was provided by TOBASA bioindustrial de babaçu S.A
Company, located in Tocantinopolis -Tocantins State. Endocarp meal type I have a thin powdery grain size that is separated by a suction system and is composed only by the endocarp part of the coconut. The chemical composition of BEMII is shown in Table 1. BEMII has a coarse particle size and is rich in fiber bundles and small pieces of almonds (Figure 1).

Table 1. Chemical composition of BEMII on dry matter (\% DM).

\begin{tabular}{cc}
\hline Items & BEMII \\
\hline DM (\%) & 80.36 \\
CP & 8.79 \\
EE & 4.79 \\
NDF & 74.37 \\
ADF & 61.44 \\
Cellulose & 42.59 \\
Lignins & 20.85 \\
TDN & 41.74 \\
\hline
\end{tabular}

Dry matter (DM), crude protein (CP), ether extract (EE), fiber in neutral detergent (NDF), fiber in acid detergent (ADF), total digestible nutrients (TDN).

Twenty non-castrated male sheep with an undefined breed $(20 \pm 3.8 \mathrm{~kg}$ mean weight) were distributed in a completely randomized design with four treatments of perceptual inclusion of BEMII in the dry matter diet $(0 \%, 7.5 \%, 15.0 \%$, and $22.5 \%)$. The sheep were previously treated for parasites and housed in metabolism cages with water dispensers, plastic feeders, and appropriate devices for urine and feces collection. The diets had similar levels of neutral detergent fiber (NDF) and total digestible nutrients (TDN) and were formulated according to NRC (2007) (Table 2). 
Figure 1. Endocarp of Babassu.

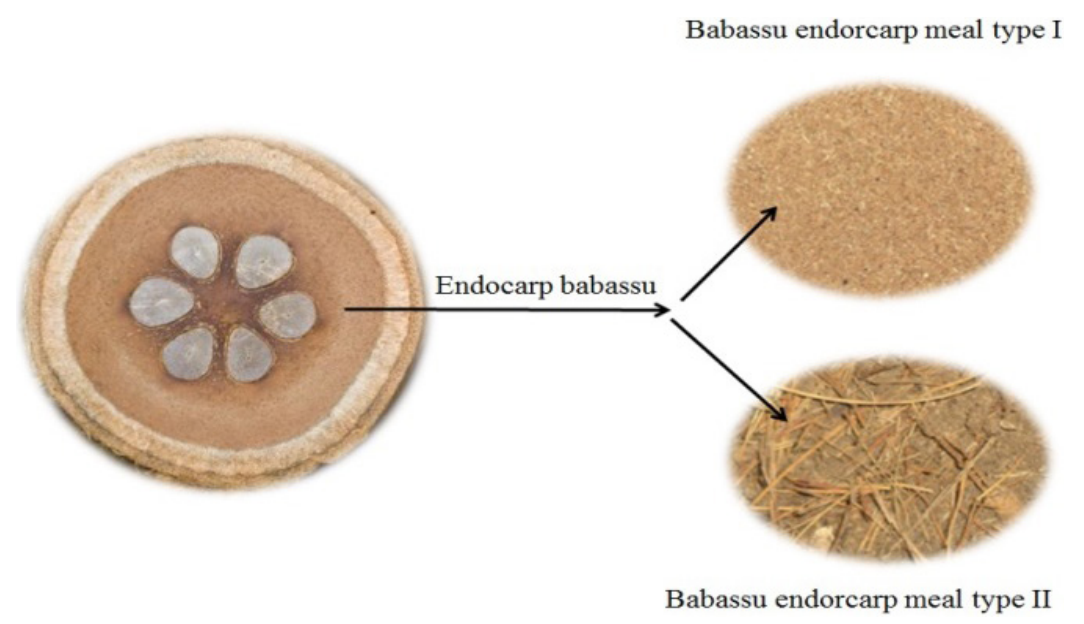

Table 2. Chemical composition and ingredient proportion in rations given to male lambs containing BEMII.

\begin{tabular}{ccccc}
\hline & \multicolumn{3}{c}{ Inclusions of BEMII in \% of DM } \\
\cline { 2 - 4 } Items & 0.0 & 7.5 & 15.0 & 22.5 \\
\hline DM \% & 87.40 & 79.18 & 73.62 & 78.05 \\
NDF & 35.20 & 34.67 & 34.13 & 33.60 \\
CP & 12.00 & 12.00 & 12.00 & 12.00 \\
TDN & 60.00 & 60.00 & 60.00 & 60.00 \\
\hline \multicolumn{5}{c}{ Ingredient proportion in \% of DM } \\
Napier Silage & 44.29 & 35.41 & 26.52 & 17.64 \\
Corn & 30.78 & 33.01 & 35.24 & 37.46 \\
Soybean Meal & 15.87 & 14.83 & 13.80 & 12.76 \\
Phosphate & 3.44 & 3.65 & 3.85 & 4.06 \\
Mineral Salt & 3.00 & 3.00 & 3.00 & 3.00 \\
Limestone & 2.60 & 2.58 & 2.57 & 2.55 \\
BEMII & - & 7.50 & 15.00 & 22.50 \\
\hline
\end{tabular}

Dry matter (DM), crude protein (CP), fiber in neutral detergent (NDF), fiber in acid detergent (ADF), total digestible nutrients (TDN). Assurance levels (nutrient kg-1): calcium-150 g; sulfur-12 g; phosphorus -65 g; magnesium-6 mg; sodium-107 g; copper-100 mg; cobalt-175 mg; iron-1000 mg; maximum Fluor-650 mg; iodine-175 mg ; manganese-1440 mg; selenium-27 mg and zinc-6000 mg.

The period of animal adaptation to the diets and cages was 15 days, following a collection period (experimental treatment) of five days. The animals were weighed at the beginning of the adaptation period. The diet was offered in two meals daily (8:00 AM and 4:00 PM). The first meal contained $40 \%$ of the daily offered meal, aiming to optimize the consumption before high temperatures occurred later in the day. Samples of the daily offered diet, meal refusals, feces, and urine were taken and weighed daily. A compound sample for each animal of all four parameters was also collected during the five-day experimental period. The daily offered diet, meal refusal, and feces samples were dried, ground in a knife mill, sorted with a 1-mm mesh sieve and stored for further laboratory analyses. Hydrochloric acid $(100 \mathrm{ml}$ of $\mathrm{HCl} 2 \mathrm{~N})$ was added to the urine collecting buckets on the eve of each sampling event to avoid nitrogen losses through volatilization. Total urine volume was weighed, and for each 
sheep, samples containing $20 \%$ of the total amount of the liquid collected daily were taken. These samples were placed in plastic vials (one compound sample per each animal) and immediately frozen to $-18^{\circ} \mathrm{C}$. Laboratory analyses were conducted at the Laboratory of Animal Nutrition in the Veterinary School of Federal University of Minas Gerais. Dry matter (DM), ashes, ether extract (EE), and crude protein (CP) were determined according to the methodology proposed by AOAC (1995). Neutral detergent fiber (NDF), acid detergent fiber (ADF), cellulose, hemicelluloses, and lignin were determined using the methodology by Van Soest et al. (1991) to determine the total carbohydrate estimation $(\mathrm{TCH})$. The equation proposed by Sniffen et al. (1992) was used where

$$
\mathbf{T C H}=100-(\% \mathbf{C P}+\% \mathbf{E E}+\% \mathbf{M M}) .
$$

\section{[(nutrient consumption in grams - nutrient quantity in grams in feces)} / nutrient consumption in grams]/100

Gross energy (GE) was obtained in adiabatic calorimeter model PARR 1281. To obtain urine GE, $10 \mathrm{ml}$ of this liquid was put in a plastic glass and taken to the air forced ventilation oven (55$60^{\circ} \mathrm{C}$ ) for $72 \mathrm{~h}$ for pre-drying, and then to the bomb calorimeter for burning. Six empty plastic glasses
To estimate non-fibrous carbohydrates (NFC), the equation proposed by Hall et al. (1999) was used:

$$
\mathrm{NFC}=\% \mathbf{T C H}-\% \text { NDFcap, }
$$

where NDFcap is the portion of NDF corrected for ashes and protein. To calculate TDN, the equation proposed by Weiss (1999) was used:

$\mathrm{TDN}=[\mathrm{DCP}+\mathrm{DNFC}+\mathrm{DNDF}$ cap $+(\mathrm{DEE} * \mathbf{2 . 2 5})]$,

where DCP, DNFC, DNDFcap, and DEE is the consumption of the digestible fractions of $\mathrm{CP}$, NFC, NDFcap and EE. Dry matter, crude protein, ether extract, neutral detergent fiber, acid detergent fiber, cellulose, hemicellulose and gross energy coefficient determinations were made using the following formula:

\section{Gross Energy Intake (IGE) - Excreted Gross Energy in feces [EGEF] .}

Metabolizable Energy (ME) was calculated Clapperton (1965): using the formula proposed by Blaxter and

\section{$\mathrm{ME}=\mathrm{DE}-($ Urine Gross Energy [UGE] + Gases Energy [GE] .}

Methane production was estimated as follows:

$$
\mathrm{MP}=0.67+0.062 \mathrm{D},
$$

where $\mathrm{MP}=$ methane production in $\mathrm{Kcal}^{-1} 100$ kcal of energy intake, and $\mathrm{D}=$ apparent digestibility of the feed GE.

Nitrogen balance was also calculated using the following: 


\section{(Nitrogen Intake (NI) - [Fecal Nitrogen [FN] + Urinary Nitrogen [UN]] 。}

where NI $=$ Offered Nitrogen - Feed-refusal Nitrogen.

The means were compared using the StudentNewman-Keuls test. Treatment effects were declared significant at $\mathrm{P}<0.05$ and were considered marginal when p-values ranged from 0.05 to 0.15 , unless otherwise noted. Regression analysis was performed using software SAEG (SAEG, 2007) to allow estimation of the intake and digestibility of the inclusions as a function of the byproduct within the range studied. Different mathematical models (linear, polynomial, exponential, and logarithmic) were tested by the procedure "Models Pre-defined," and the one that presented the best fit with the highest determination coefficient was chosen. Next, it was observed whether the same model fit the biological response studied. The equations shown in this work were selected to provide greater confidence and better applicability to forecast consumption values and digestibility.

\section{Results and Discussion}

The intake of dry matter (DMi) according to body weight ( $\mathrm{g} / \mathrm{BW})$ and metabolic weight $\left(\mathrm{g} / \mathrm{kg}^{0.75}\right)$ were negatively affected by the increasing inclusions of the byproduct (Table 3). BEMII is known to be a highly fibrous feed (74.37\% NDF; 20.85\% lignin) that may negatively affect animal consumption. Special care has to be taken when using Babassu coproducts, even in diets calculated to have the same NDF content. Previous researches have related the decrease in the DMi due to physical factors that may cause ruminal filling (SOUSA JUNIOR et al., 2007; XENOFONTE et al., 2008).

Crude protein intake (CPi) declined linearly $(\mathrm{P}<0.05)$, with a reduction of $49.35 \mathrm{~g} /$ day when compared to the $22.5 \%$ BEMII inclusion at $0 \%$. This relates to a decline of $2.19 \mathrm{~g}$ for each $1 \%$ of BEMII participation. According to NRC
(1985), CPi must be 160 to $191 \mathrm{~g} /$ day to meet the requirements of the animals used in the same category of this experiment. However, none of the experimental diets complied with the animal protein requirements. $\mathrm{CPi}$ represented by percent $\mathrm{BW}$ and $\mathrm{g} / \mathrm{kg}^{0.75}$ showed a quadratic behavior and, according to Van Soest (1994), low nitrogen diets were associated with intake reduction. The high levels of the acid detergent insoluble nitrogen (ADIN) could reflect the low protein availability to the ruminal microorganisms.

For ether extract intake (EEi), differences were found $(\mathrm{P}<0.05)$ between the inclusions for both grams/day and percent BW, where a lower intake of $3.73 \mathrm{~g}$ /day for animals that received $22.5 \%$ of BEMII inclusion. Miotto et al. (2012) studied intake and digestibility of Babassu mesocarp meal levels in sheep diets and detected a reduction in EEi for percent $\mathrm{BW}$ and $\mathrm{g} / \mathrm{kg}^{0.75}$ with increasing inclusions of the byproduct. This reduction was attributed to the Napier grass silage used in that experiment, whose EE levels were three times superior when compared to Babassu mesocarp meal $(1.9 \%$ and $0.7 \%$ of EE, respectively). The Napier grass silage used in this experiment had an EE content of 2.4\%. In addition to the rich fiber bundles in the endocarp, BEMII contains small pieces of almonds that increase the EE content to $4.79 \%$. However, due to the sheep's ability to select food, it was observed that the animals showed greater preference for silage, since the orts collected corresponded mainly to BEMII. This behavior was responsible for the decreasing EEi levels with increasing inclusions of the byproduct.

Apparent digestibility coefficients of nutrients, the regression equations and determination and variation coefficients are shown in Table 4 . The dry matter and crude protein digestibility was significantly affected by BEMII. The downward quadratic response revealed superior crude protein 
digestibility when there was no byproduct inclusion. protein digestibility when $20 \%$ of Babassu cake was Sousa Junior et al. (2007) found a reduction in crude included in sheep diets.

Table 3. Nutrient intake by lambs fed diets containing different levels of BEMII.

\begin{tabular}{|c|c|c|c|c|c|c|c|}
\hline \multicolumn{8}{|c|}{ Intake in grams animal for day } \\
\hline & 0.0 & 7.5 & 15.0 & 22.5 & $\mathrm{CV}$ & Regression equation & $\mathrm{R}^{2}$ \\
\hline $\mathrm{DMi}$ & 904.11 & 881.73 & 793.65 & 745.46 & 37.1 & - & - \\
\hline $\mathrm{CPi}$ & 147.64 & 134.09 & 91.19 & 98.29 & 37.7 & $Y=-2.5461 X+146.449$ & 81.2 \\
\hline $\mathrm{EEi}$ & 7.24 & 7.84 & 7.40 & 3.73 & 44.2 & $Y=-1.06 X^{2}+4.24 X+3.95$ & 95.7 \\
\hline NDFi & 166.62 & 205.60 & 203.08 & 233.03 & 37.0 & - & - \\
\hline ADFi & 76.63 & 101.73 & 121.36 & 117.40 & 36.3 & - & - \\
\hline Hceli & 89.99 & 103.87 & 81.71 & 115.62 & 40.5 & - & - \\
\hline CELi & 61.77 & 71.77 & 79.79 & 79.29 & 37.9 & - & - \\
\hline LIGi & 14.57 & 25.95 & 20.14 & 30.68 & 39.2 & - & - \\
\hline TCHOi & 592.99 & 641.18 & 608.22 & 574.94 & 36.5 & - & - \\
\hline $\mathrm{NFCi}$ & 397.94 & 386.75 & 385.33 & 317.83 & 34.8 & - & - \\
\hline TDNi & 421.25 & 420.36 & 410.74 & 395.78 & 33.0 & - & - \\
\hline \multicolumn{8}{|c|}{ Intake $\mathrm{g} / \mathrm{BW}$} \\
\hline DMi & 4.38 & 4.28 & 4.10 & 3.82 & 7.1 & $Y=-0.2513 \mathrm{X}+4.43056$ & 95.1 \\
\hline $\mathrm{CPi}$ & 0.71 & 0.65 & 0.47 & 0.50 & 6.1 & $Y=0.02 X^{2}-0.20 X+0.91$ & 86.2 \\
\hline EEi & 0.03 & 0.03 & 0.04 & 0.02 & 16.6 & $Y=-0.005 X^{2}+0.02 X+0.01$ & 92.7 \\
\hline NDFi & 0.79 & 0.98 & 1.05 & 1.19 & 9.3 & $Y=0.167893 X+0.80562$ & 96.9 \\
\hline ADFi & 0.36 & 0.49 & 0.63 & 0.60 & 13.8 & $Y=-0.007 X^{2}+0.27 X+0.35$ & 97.3 \\
\hline Hceli & 0.43 & 0.48 & 0.42 & 0.59 & 10.6 & - & - \\
\hline CELi & 0.29 & 0.35 & 0.41 & 0.41 & 15.0 & $Y=0.053547 X+0.30606$ & 84.8 \\
\hline LIGi & 0.06 & 0.12 & 0.10 & 0.16 & 19.8 & - & - \\
\hline TCHOi & 2.86 & 3.10 & 3.15 & 2.95 & 7.5 & $Y=-0.01 X^{2}+0.48 X+2.86$ & 98.9 \\
\hline $\mathrm{NFCi}$ & 1.97 & 1.88 & 2.01 & 1.61 & 28.4 & - & - \\
\hline TDNi & 2.11 & 2.01 & 2.12 & 2.02 & 23.3 & - & - \\
\hline \multicolumn{8}{|c|}{ Intake $\mathrm{g} / \mathrm{kg}^{0.75}$} \\
\hline $\mathrm{DMi}$ & 92.09 & 90.46 & 85.30 & 79.94 & 12.3 & $Y=-73.4 X^{2}+0.02 X+0.35$ & 95.1 \\
\hline $\mathrm{CPi}$ & 15.08 & 13.82 & 9.80 & 10.56 & 11.3 & $Y=0.50 X^{2}-4.29 X+19.24$ & 85.2 \\
\hline EEi & 0.72 & 0.80 & 1.86 & 0.40 & 19.9 & - & - \\
\hline NDFi & 16.76 & 20.93 & 21.79 & 25.02 & 14.6 & $Y=0.341387 X+17.2864$ & 94.7 \\
\hline ADFi & 7.67 & 10.51 & 13.08 & 12.60 & 16.8 & $Y=0.231573 X+8.3608$ & 82.8 \\
\hline Hceli & 9.09 & 10.41 & 8.71 & 12.41 & 17.1 & $Y=0.108373 X+6.4598$ & 86.1 \\
\hline CELi & 6.17 & 7.45 & 8.59 & 8.50 & 18.2 & - & - \\
\hline LIGi & 1.54 & 2.74 & 2.13 & 3.24 & 17.7 & - & - \\
\hline TCHOi & 60.23 & 65.65 & 65.42 & 61.72 & 12.6 & - & - \\
\hline $\mathrm{NFCi}$ & 41.83 & 39.77 & 41.71 & 33.84 & 29.4 & - & - \\
\hline TDNi & 45.32 & 42.67 & 44.17 & 42.26 & 25.2 & - & - \\
\hline
\end{tabular}

Dry matter intake (DMi), crude protein intake (CPi), ether extract intake (EEi), fiber in neutral detergent intake (NDFi), fiber in acid detergent intake (ADFi), hemicellulose intake (Hceli), cellulose intake (CELi), lignin intake (LIGi), total carbohydrates intake (TCHOi), non-fibrous carbohydrate intake (NFCi), total digestible nutrients intake (TDNi), coefficient of variation in \% (CV), coefficient of determination in $\%\left(\mathrm{R}^{2}\right)$. 
BEMII is characterized by its fibrous composition (41.00\% NDF; 20.85\% lignin). Lousada Júnior et al. (2005), working with intake and digestibility of processed fruit co-products in sheep diets (acerola, guava, pineapple passion fruit and melon), observed reductions on DM and
CP digestibility in acerola and guava co-products, which have fibrous characteristics similar to BEMII (39.3\% and $35.0 \%$ of NDIN; $20.1 \%$ and $18.5 \%$ of lignin, respectively) These results corroborate our results and demonstrate how lignin levels can negatively influence digestibility and promote low degradability of co-products.

Table 4. Digestibility coefficients in percentage of nutrients of male lambs fed with different inclusion levels of BEMII.

\begin{tabular}{|c|c|c|c|c|c|c|c|}
\hline \multicolumn{8}{|c|}{ Inclusions of BEMII in \% of DM } \\
\hline & 0.0 & 7.5 & 15.0 & 22.5 & $\mathrm{CV}$ & Regression Equation & $\mathrm{R}^{2}$ \\
\hline $\mathrm{DMd}$ & 74.94 & 69.77 & 69.58 & 69.55 & 4.4 & $Y=0.02 X^{2}-0.73 X+74.70$ & 94.49 \\
\hline $\mathrm{CPd}$ & 78.29 & 76.00 & 68.86 & 73.09 & 6.1 & $Y=0.02 X^{2}-0.95 X+79.10$ & 73.38 \\
\hline EEd & 60.04 & 61.21 & 71.32 & 51.71 & 16.9 & - & - \\
\hline NDFd & 65.21 & 50.46 & 48.34 & 57.97 & 11.0 & $Y=0.10 X^{2}-2.75 X+65.17$ & 97.98 \\
\hline $\mathrm{ADFd}$ & 46.22 & 38.48 & 40.09 & 41.73 & 18.9 & - & - \\
\hline HCELd & 80.32 & 63.26 & 60.65 & 74.12 & 9.5 & $Y=0.13 X^{2}-3.33 X+80.40$ & 94.95 \\
\hline CELd & 61.24 & 48.08 & 48.59 & 50.28 & 16.5 & $Y=0.06 X^{2}-1.92 X+60.61$ & 93.09 \\
\hline TCHOd & 80.20 & 76.10 & 75.24 & 74.77 & 3.1 & $Y=0.016 X^{2}-0.59 X+80.06$ & 97.79 \\
\hline NFCd & 69.32 & 81.95 & 84.15 & 79.55 & 9.6 & - & - \\
\hline TDN & 50.08 & 48.34 & 47.77 & 47.39 & 10.3 & - & - \\
\hline
\end{tabular}

Dry matter digestibility (DMd), crude protein digestibility (CPd), ether extract digestibility (EEd), neutral detergent fiber digestibility (NDFd), acid detergent fiber digestibility (ADFd), hemicellulose digestibility (Hceld), cellulose digestibility (CELd), total carbohydrates digestibility (TCHOd), non-fiber carbohydrates digestibility (NFCd), total digestible nutrients (TDN), coefficient of variation in $\%(\mathrm{CV})$; coefficient of determination in $\%\left(\mathrm{R}^{2}\right)$.

Neutral detergent fiber digestibility was significantly influenced by BEMII inclusion. It is inferred that the fiber content in BEMII was potentially digestible through slow ruminal fermentation. Sousa et al. (2014), working with chemical composition and ruminal fermentation kinetics of Babassu mesocarp ratios, warned about NDF byproduct levels and their influence on ruminal fermentation kinetics. The authors described a possible restriction of this type of food for ruminant diets during the late gestation or lactation period, in particular for animals with high nutrition demands, such as ruminants with high productive potential.

There were no differences $(\mathrm{P}<0.05)$ between treatments for gross energy intake (GEi) is shown in Table 5. Digestible energy intake (DEi), urine gross energy (UGE), and energy balance resulted in a quadratic behavior, but remained positive at all byproduct inclusion levels. Metabolizable energy intake (MEi) showed a decreasing linear behavior similar to the $940 \mathrm{kcal}^{-1}$ day reported in NRC (2007). Therefore, it is concluded that only the inclusion level of $7.5 \%$ was satisfactory, and he other levels remained above the NRC (2007) recommendations. The decrease in apparent digestibility of gross energy (ADGE) may have occurred due to the highly fibrous byproduct characteristics reflected in the low fiber digestibility.

The mean values of nitrogen balance for all four treatments are presented in Table 6. There 
was a significant difference $(\mathrm{P}<0.05)$ between the treatments for nitrogen intake $(\mathrm{Ni})(\mathrm{g} / \mathrm{d})$, and nitrogen balance (NB) presented a quadratic behavior due to the byproduct inclusion level. Van Soest (1994) affirmed that diets poor in soluble carbohydrates and rich in lignin, such as this byproduct, limit nonprotein nitrogen because of the small energy content and low digestion of available carbohydrates.

Table 5. Gross energy intake (GEi), apparent digestibility of gross energy (ADGE), digestible energy intake (DEi), metabolizable energy intake (MEi), urine gross energy (UGE), and energy balance (EB) due to different inclusion levels of BEMII.

\begin{tabular}{|c|c|c|c|c|c|c|c|}
\hline \multicolumn{8}{|c|}{ Inclusions of BEMII in $\%$ of DM } \\
\hline & 0.0 & 7.5 & 15.0 & 22.5 & $\mathrm{CV}$ & Regression Equation & $\mathrm{R}^{2}$ \\
\hline $\mathrm{GEi}^{*}$ & 2540.66 & 2400.35 & 2385.98 & 2359.87 & 37.6 & & \\
\hline ADGE \% & 79.17 & 72.17 & 66.71 & 69.65 & 6.1 & $Y=441.61 X^{2}-144.8 X+79.5$ & 96.5 \\
\hline $\mathrm{DEi}^{*}$ & 1971.54 & 2037.47 & 1604.19 & 1663.22 & 38.3 & & \\
\hline $\mathrm{MEi}^{*}$ & 1324.10 & 1193.57 & 749.23 & 887.61 & 36.1 & $Y=-2338.4 X+1302.7$ & 75.3 \\
\hline $\mathrm{UGE}^{*}$ & 77.59 & 80.30 & 72.45 & 78.25 & 33.2 & & \\
\hline $\mathrm{EB}^{*}$ & 1893.94 & 1957.17 & 1531.74 & 1584.97 & 39.8 & $Y=-445.43 X^{2}-17.1 X+18.3$ & 67.2 \\
\hline
\end{tabular}

${ }^{*}$ Kcal; coefficient of variation in \% $(\mathrm{CV})$; coefficient of determination in \% $\left(\mathrm{R}^{2}\right)$.

Table 6. Nitrogen intake (Ni) (g/day), fecal nitrogen (FN) (g/day), urinary nitrogen (UN), and nitrogen balance (NB) due to different inclusion levels of BEMII.

\begin{tabular}{cccccccc}
\hline & \multicolumn{7}{c}{ Inclusions of BEMII in \% of DM } \\
\hline & 0.0 & 7.5 & 15.0 & 22.5 & $\mathrm{CV}$ & Regression equation & $\mathrm{R}^{2}$ \\
\hline $\mathrm{Ni}$ & 23.62 & 21.46 & 14.60 & 15.73 & 23.5 & $\mathrm{Y}=146.08 \mathrm{X}^{2}-73.57 \mathrm{X}+24.26$ & 85.6 \\
$\mathrm{FN}$ & 5.35 & 5.05 & 4.38 & 4.17 & 32.7 & - & - \\
$\mathrm{UN}$ & 6.69 & 5.01 & 4.85 & 3.86 & 27.4 & $\mathrm{Y}=-11.573 \mathrm{X}+6.405$ & 90.5 \\
$\mathrm{NB}$ & 11.58 & 11.39 & 5.36 & 7.70 & 40.6 & $\mathrm{Y}=113.44 \mathrm{X}^{2}-48.86 \mathrm{X}+12.4$ & 73.3 \\
\hline
\end{tabular}

coefficient of variation in \% $(\mathrm{CV})$; coefficient of determination in $\%\left(\mathrm{R}^{2}\right)$.

High correlation was found between NB and EB ( $r=0.92 ; \mathrm{P}<0.01)$, most likely because of the dietary protein level over digestion and microbial fermentation, as well as the effect of the incorporated amino acid profile and the energy available for production and animal metabolism. The 7.5\% inclusion level was the best among all the inclusions for $\mathrm{EB}$, and presented a very close NB value when compared to the control group. This inclusion has the best point of use for BEMII, providing better synchronization between energy demands and microbial fermentation, thereby guaranteeing better animal performance.

The increase of BEMII concentration in the diets resulted in a linear decrease of water intake $\left(\mathrm{IH}_{2} \mathrm{O}\right)$ intake (Table 7.) due to the larger consumption of water from the higher dry matter intake (Table 3.) Water intake in relation to NDF intake decreased as BEMII levels increased. This was due to the slow digestions in the high NDF content diet and remained in the animal intestinal tract, reducing DMi and water intake, since water spent with salivation would not have to be supplied in a more intense rumination process. 
Table 7. Water intake ( $\mathrm{H}_{2} \mathrm{Oi}$ ), hydric balance (HB), urine volume (UV), and urine gravity (UG) due to different inclusion levels of BEMII.

\begin{tabular}{|c|c|c|c|c|c|c|c|}
\hline \multicolumn{8}{|c|}{ Inclusions of BEMII in $\%$ of DM } \\
\hline & 0.0 & 7.5 & 15.0 & 22.5 & $\mathrm{CV}$ & Regression Equation & $\mathrm{R}^{2}$ \\
\hline $\mathrm{H}_{2} \mathrm{Oi}$ & 2.74 & 2.59 & 2.12 & 1.66 & 28.53 & $\mathrm{Y}=2.838400-0.049413 \mathrm{X}$ & 95.85 \\
\hline $\mathrm{H}_{2} \mathrm{Oi} \mathrm{DMi}^{-1}$ & 3.33 & 3.04 & 2.67 & 2.32 & 23.40 & $\mathrm{Y}=3.352600-0.045387 \mathrm{X}$ & 99.69 \\
\hline $\mathrm{H}_{2} \mathrm{Oi} \mathrm{NDFi}^{-1}$ & 18.76 & 13.22 & 10.49 & 7.39 & 31.88 & $Y=18.039000-0.4926 X$ & 99.69 \\
\hline $\mathrm{H}_{2} \mathrm{Oi} / \mathrm{BW}$ & 14.50 & 13.02 & 10.98 & 8.70 & 21.98 & $\mathrm{Y}=14.722400-0.25928 \mathrm{X}$ & 99.15 \\
\hline $\mathrm{H}_{2} \mathrm{Oi} / \mathrm{MW}$ & 0.29 & 0.27 & 0.22 & 0.18 & 18.09 & $\mathrm{Y}=0.303400-0.005280 \mathrm{X}$ & 98.70 \\
\hline HB & 2.24 & 2.29 & 1.85 & 1.52 & 31.15 & $\mathrm{Y}=2.372200-0.034907 \mathrm{X}$ & 86.53 \\
\hline UV & 1.47 & 1.23 & 1.03 & 0.85 & 41.05 & $Y=1.453600-0.027387 X$ & 99.54 \\
\hline UG & 1.03 & 1.03 & 1.04 & 1.03 & 1.65 & - & - \\
\hline
\end{tabular}

$\mathrm{H}_{2} \mathrm{Oi} \mathrm{DMi}{ }^{-1}=$ Water intake in percentage of dry matter intake $\left(\mathrm{L} \mathrm{kg}^{-1}\right) ; \mathrm{H}_{2} \mathrm{Oi} / \mathrm{BW}=$ Water intake in percentage of body weight $(\%)$; $\mathrm{H}_{2} \mathrm{Oi} / \mathrm{MW}=$ Water intake in percentage of metabolic weight $\left(\mathrm{L}^{-1} \cdot \mathrm{kg}^{0.75}\right) ; \mathrm{NB}=$ Hydric balance $($ water intake + food water - urine water in feces) in (L); coefficient of variation in \% (CV); coefficient of determination in $\%\left(\mathrm{R}^{2}\right)$.

The diet with greater BEMII inclusion (22.5\%) presented a lower hydric balance $(1.52 \mathrm{~L} /$ day $)$ and a smaller urine volume $(0.85 \mathrm{~L} /$ day $)$ due to the lower water intake $(1.66 \mathrm{~L} /$ day). Urine gravity was not altered by the experimental diets.

\section{Conclusion}

Babassu endocarp meal type II inclusions above $15 \%$ negatively affected the intake, digestibility, nitrogen and energy balance in male crossbred lambs. Thus, the inclusion of $7.5 \%$ in sheep diets is recommended to allow better animal performance.

\section{References}

ABDAllA, A. L.; SILVA FILHO, J. C.; GODOI, A. R.; CARMO, C. A.; EDUARDO, J. L. P. Utilização de subprodutos da indústria de biodiesel na alimentação de ruminantes. Revista Brasileira de Zootecnia, Viçosa, MG, v. 37, p. 260-268, 2008. Número Especial.

ASSOCIATION OF OFFICIAL ANALYTICAL CHEMISTS - AOAC. Official methods of analysis. Washington: AOAC, 1995. $1141 \mathrm{p}$.

BLAXTER, K. L.; CLAPPERTON, J. L. Prediction of the amount of methane produced by ruminants. Brittish Journal of Nutrition, London, v. 19, n. 1, p. 511-522, 1965.

HALL, M. B.; HOOVER, W. H.; JENNINGS, J. P.; WEBSTER, T. K. M. A method for partitioning neutral detergent soluble carbohydrates. Journal Science Food Agriculture, New York, v. 79, n. 15, p. 2079-2086, 1999.

LOUSADA JÚNIOR, J. E.; NEIVA, N. M.; RODRIGUEZ, N. M.; PIMENTEL, J. C. M.; LÔBO, R. N. B. Consumo e digestibilidade de subprodutos do processamento de frutas em ovinos. Revista Brasileira de Zootecnia, Viçosa, MG, v. 34, n. 2, p. 659-669, 2005.

MIOTTO, F. R. C.; RESTLE, J.; NEIVA, J. N. M.; MACIEL, R. P.; FERNANDES, J. J. R. Consumo e digestibilidade de dietas contendo níveis de farelo do mesocarpo de babaçu para ovinos. Revista Ciência Agronômica, Fortaleza, v. 43, n. 4, p. 792-801, 2012.

NATIONAL RESEARCH COUNCIL - NRC. Nutrient requirement of sheep. Washington D.C.: National Academy Press, 2007. 99 p.

NATIONAL RESEARCH COUNCILL - NRC. Nutrient requeriments of sheep. 6. ed. Washington: National Academy Press, 1985. 112p.

SISTEMA DE ANÁLISES ESTATÍSTICAS E GENÉTICAS - SAEG. Sistema de análises estatísticas e genéticas. Versão 9.1: Fundação Arthur Bernardes. Viçosa, MG: UFV, 2007.

SNIFFEN, C. J.; O'CONNOR, J. D.; VAN SOEST, P. J.; FOX, D. G.; RUSSELL, J. B. A net carbohydrate and protein system for evaluating cattle diets. II. Carbohydrate and protein availability. Journal of Animal Science, Iowa, v. 70, n. 12, p. 3562-3577, 1992.

SOLER, M. P.; VITALI, A.A. A.; MUTO, E. F. Tecnologia de quebra do coco babaçu (Orbignya speciosa). Ciência e Tecnologia Alimentos, Campinas, v. 27, n. 4, p. 717722, 2007. 
SOUSA JUNIOR, A.; OLIVEIRA, M. E.; ALVES, A. A.; AZEVÊDO, D. M. M. R.; LOPES, J. B.; ARAÚJO, D. L. C. Digestibilidade de dietas contendo farelo de babaçu para ovinos em terminação. Archivos de Zootecnia, Cordoba, v. 56, n. 216, p. 967-970, 2007.

SOUSA, L. F.; MACEDO JÚNIOR, G. L.; SANTOS, R. P.; SILVA, A. G. M.; BORGES, I. Composição bromatológica e cinética da fermentação ruminal de rações contendo resíduos de babaçu. Revista Ciência Agronômica, Fortaleza, v. 45, n. 1, p. 177-185, 2014.

SOUZA, M. P.; VALDÉS BORRERO, M. A. V.; SOUZA FILHO, T. A. Potencial para o desenvolvimento da cadeia produtiva do Babaçu no Médio e Baixo Rio MadeiraPorto Velho/Ro. Revista de Administração e Negócios da Amazônia, Porto Velho, v. 3, n. 2, p. 75-87, maio/ago. 2011.
VAN SOEST, P. J. Nutritional ecology of the ruminant. Ithaca: Cornell University Press, 1994. 476 p.

VAN SOEST, P. J.; ROBERTSON, J. B.; LEWIS, B. A. Methods for dietary fiber and nonstarch polysaccaridies in relation to animal nutrition. Journal Dairy Science, Ithaca, v. 74, n. 9, p. 3583-3597, 1991.

WEISS, W. P. Energy prediction equations for ruminant feeds. In: CORNELL NUTRITION CONFERENCE FOR FEED MANUFACTURES, 61., 1999, Ithaca. Proceedings... Ithaca: Cornell University, 1999. p. 176185.

XENOFONTE, A. R. B.; CARVALHO, F. F. R.; BATISTA, A. M. V.; MEDEIROS, G. R.; ANDRADE, R. P. X. Desempenho e digestibilidade de nutrientes em ovinos alimentados com rações contendo farelo de babaçu. Revista Brasileira de Zootecnia, Viçosa, MG, v. 37, n. 11, p. 2063-2068, 2008. 